\title{
SHARED SERVICE CENTER: MEASURING PERFORMANCE FROM THE PERSPECTIVE OF THE CUSTOMER, SUPPLIER AND THEORY
}

\author{
${ }^{* 1}$ Nathan Peixoto Oliveira, ${ }^{2}$ André Martins de Oliveira, ${ }^{3}$ Rômulo Henrique Gomes de Jesus, \\ ${ }^{4}$ Danielle Gonçalves de Oliveira Prado, ${ }^{5}$ Thiago Fernandes Lima \\ 1,2,5 Université de Bordeaux, 33000, Bordeaux-AQ, France \\ ${ }^{3}$ Universidade Tecnológica Federal do Paraná, 84016-210, Ponta Grossa-PR, Brazil \\ ${ }^{4}$ Universidade Tecnológica Federal do Paraná, 86812-460, Apucarana- PR, Brazil \\ *nathanpeixot@yahoo.com.br
}

\begin{abstract}
Shared service centers have become one of the most discussed models and have been widely diffused by companies. It helps to reduce costs and to standardize operational processes, bringing more efficiency. But there is still a dilemma under its performance, the gain in processes centralization and especially when compared to outsourcing services. The intention of this article is to demonstrate the various perceptions of this model, comparing the views of the client, the supplier and the available theory. A bibliographic review and a case study were applied and demonstrated that in shared service center, the specialisation workforce is a strong ally. Also it centralized the processes with scale gain, eliminated distance between the units, improved the information technology processes and improved communication. The case study and analysis made also can be used by professionals who consider joining such business model into their institution.
\end{abstract}

Keywords: Customer; Shared Service Center; Supplier.

\section{CENTRO DE SERVIÇO COMPARTILHADO: MEDIÇÃO DO DESEMPENHO DA PERSPECTIVA DO CLIENTE, FORNECEDOR E TEORIA}

\section{RESUMO}

Os centros de serviços compartilhados tornaram-se um dos modelos mais discutidos e foram amplamente difundidos pelas empresas. Ajuda a reduzir custos e a padronizar processos operacionais, trazendo mais eficiência. Mas ainda existe um dilema em seu desempenho, o ganho na centralização de processos e, principalmente, quando comparado aos serviços de terceirização. A intenção deste artigo é demonstrar as várias percepções desse modelo, comparando as visões do cliente, do fornecedor e da teoria disponível. Uma revisão bibliográfica e um estudo de caso foram aplicados e demonstraram que no centro de serviços compartilhados, a força de trabalho da especialização é um forte aliado. Também centralizou os processos com ganho de escala, eliminou a distância entre as unidades, melhorou os processos de tecnologia da informação e melhorou a comunicação. O estudo de caso e a análise realizados também podem ser utilizados por profissionais que consideram aderir a esse modelo de negócios em sua instituição. 
Palavras-chave: Cliente; Centro de Serviços Compartilhados; Fornecedor.

\section{Como Citar:}

OLIVEIRA, Nathan Peixoto et al. Shared Service Center: measuring performance from the perspective of the customer, supplier and theory. In: SIMPÓSIO DE PESQUISA OPERACIONAL E LOGÍSTICA DA MARINHA, 19., 2019, Rio de Janeiro, RJ. Anais [...]. Rio de Janeiro: Centro de Análises de Sistemas Navais, 2019.

\section{INTRODUCTION}

Shared service centers have become one of the most discussed models in theory and in application by companies. The firsts records are from the 1990s, and would have started in the US, was an initial structure and different what is known today (QUINN; COOKE; KRIS, 2000). In the following years, the model spread and had fans in the European market (MILLER, 1999). According to Schulman, Harmer and Lusk (2001) reports that the first the role played by a shared service center was only related the financial and limited to certain types of activities. Over time others services have been migrating to shared centers such as HR, marketing and communication.

The shared service centers had as objective, first cost reduction and later standardization of activities (MILLER, 1999). However, with the model consolidation and the advance in technology, the shared service centers play an important role in the company's strategy and the search for competitive advantage (RUDZIONIENE; SAKALAUSKIENE, 2014)

The Delloite International Conference 2017 discussed the constants changes in model based on the technological advances and what will be their future steps. At present, shared services centers, which until then were local centers, are migrating to global solutions called GBS - Global Business Solutions. Another benefit recognized by technological advancement is the RPA - Robotic Process Automation, companies are opting for automation solutions with the goal of further reducing costs and standardizing routines. So, Shared Service is a constant change and updated model to adapt to the challenges of the market.

The intention of this study is to review the literature on the topic and explain the purpose of each type of approach, in order to demonstrate through field research how it is applied in reality.

The methodology used for the study was the bibliographic research in conjunction with a case study.

According to Vergara (2010), the research can be divided regarding the ends and the means. The means include the following research: exploratory, descriptive, explanatory, methodological, applied, interventionist.

For the present study an exploratory research will be done. According to Vergara (2010, p. 42), exploratory research is not an exploratory reading, since it is carried out in an area that seeks greater knowledge. By its nature, it is not hypothetical.

The means of investigation can be: field research, laboratory research, documentary, bibliographical, experimental, ex post facto, participant, action research, case study.

For the data collection, a questionnaire was formulated based on the bibliography studied, and in this way to make the intersection with the reality lived in Tobacco. In parallel, there was an interaction with the employees of the company, to conceptualize the study and facilitate the understanding of the objective by the respondents 
The number of participating companies gives the limitation of this research, only one company was chosen because the author had easy access to the information. Another limiting factor is the research done in which it was applied to a sample of the entire population, the finance area was chosen for the application of the questionnaire. The number of participants was 30, 15 for each company, that represent approximately 30\% of total financial workers in Shared Service and approximately $21 \%$ of total financial employees in Tobacco Company. In other words, the case study was done in a specific market and specific department in both companies, for this reason, the results founded could be specific that context, is not possible to affirm that results will be the same in a bigger and different scenario.

\section{LITERATURE REVIEW}

With the growth of globalization, business challenges and strategies have become global, so shared service centers are emerging as a new structure that can meet this demand quickly, with quality and lower cost. The emergence of Shared Service as we know it today started in the US, but with a different format. According to Quinn, Cooke and Kris (2000) there is no doubt that it was created in the USA and had finances as the first area of activity. One of the firsts records, even if not the same name, General Electric created an area called "Customer Service Business", with processes and characteristics similar to those found today in Shared Services.

In the same line of thought, Rudzioniene and Sakalauskiene (2014) argue that the development of the first shared service centers dates back to the beginning of the 1990s and quickly became notorious among companies. Shared service centers are whole entities, in which they create value for the organization, in addition having a certain level of management and autonomy.

In agreement with the others authors, Miller (1999) observes that the shared service center had in its early days the US in 1990s, as a financial support service, and in Europe the first conceptions that have been registered are from the middle 1990s. Multinational companies around the world, mainly due to the technologies developed and the expectation of cost reductions, initially in the financial support areas, spread the concept of a shared service center rapidly. (MILLER, 1999).

In the figure below, it is possible to visualize the evolution of the shared services centers over time, according to PWC 2017 report. At the beginning, the activities were developed decentralized, in a second moment the structures are consolidated with more structured activities, with the technology as support these activities. Moreover, in the third time, what we are experiencing today, are global structures, in which it provides service on a world scale.

Figure 1: PWC Survey 2017 - Shared Service centers evolution. 


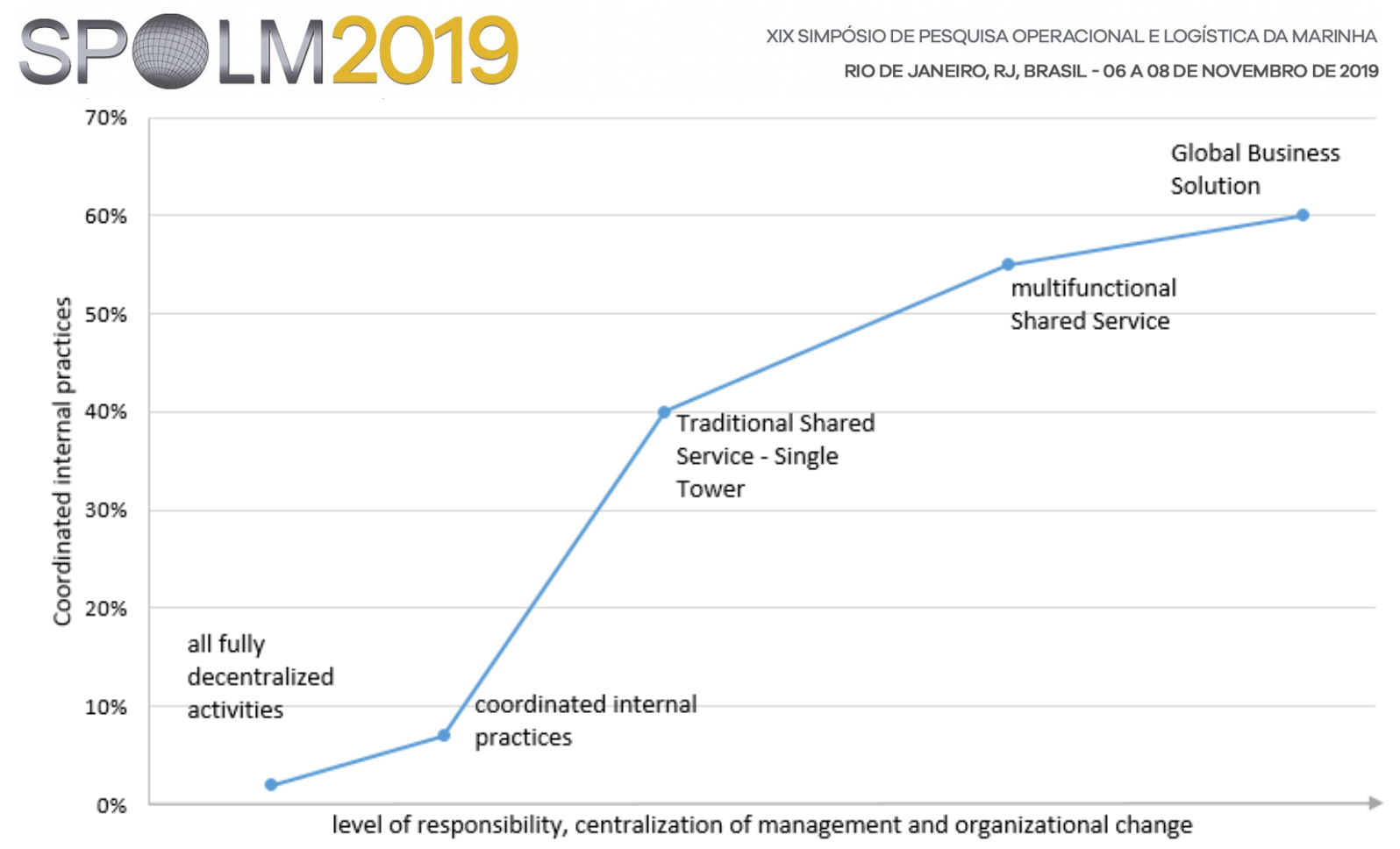

Source: adapted from PWC Survey (2017)

Still in the same focus of global centralization, according to Hope and Player (2012), many companies are allocating their shared service centers in lower cost countries, creating yet another factor of great relevance to the context. The option of implementing a shared service center brings changes in several areas of the company, such as finance, information technology and HR, and implementation in other countries generates a major change in culture as well.

Pniewski and Kalawa (2009) provides a more comprehensive and detailed description of the benefits of deploying a shared service center. Cost cutting and greater financial management, standardization of processes, better service received by the company for support processes, and better use of technologies and systems are mentioned. Allowing the business to concentrate the energies in the main business, besides offering the opportunity of continuous improvement of processes and development of people with the new structure formed.

Thus, in the context of the shared service center it is possible to obtain a number of advantages for the business. According to Quinn, Cooke and Kris (2000), companies opt for shared services to avoid duplicate activities; such practice is done between organizations, or the most common, between business units within the same companies. A shared service center is a corporate structure whose function is to combine non-strategic activities divided by the company, with the objective of serving internal clients with superior quality external outsourcing and generating value for the company (SCHULMAN; HARMER; LUSK, 2001; PETKOVIC; LAZAREVIC, 2012; LA SALLE, 2009).

According to Cooke (2006) in spite of several studies in the area, there is still no consensus on the effective success of the model, and the literature on the subject is scarce and unorganized (RICHTER; BRUHL, 2016). The option to create a Shared Service must know that the financial and emotional costs can be more impacting than the expected cost savings. The decision to adopt a Shared Service should be a structured process and analyzed by the company before joining the service sharing, deploying just to "keep up" the changes in the market can be a misguided strategy (URICH, 1995). 


\subsection{SHARED SERVICES IN BRAZIL}

Brazil is gaining global notoriety for implementations of Shared Services Centers with local, regional or global reach. According to Patino et al. (2014), in studies carried out, it was concluded that Brazil is the destination of several shared service centers, mainly by the skilled labor available, market influence and representativeness, fiscal incentives that allow smaller investments of companies and geographic location, mainly in comparison of the time zone with the American Market.

The GSLI (Global Service Location Index) issues an annual ranking with the best countries to deploy a shared service center. The study is based on 38 metrics, then divided into three different groups, which are: financial attractiveness, in which it verifies among others the financial security of the country. The second group refers to people, in which analyzes the skills and availability, among the most important skills is the mastery of the language, and the last group is the business environment that one of the pillars is the structure that the country offers to companies.

Brazil has a privileged position in last year's ranking in $4^{\text {th }}$ place. In the last analysis conducted, in 2016, Brazil won 4 positions in relation to 2015, mainly motivated by the gain in exchange variation, which made the country to gain some positions in the list. Comparing with India and China, first and second place respectively, Brazil equates to the items of financial attractiveness and business environment with the leaders, but when confronting the topic of people, the leaders have a great advantage related to Brazil.

\subsection{OUTSOURCING VS SS}

According to Quinn, Cooke and Kris (2000), is not possible a complete disassociation between shared service centers and outsourcing is difficult, while the shared service center becomes a separate entity, this is closer to internal outsourcing, and it is possible that this service, if well executed and stabilized, can be offered to the market, making it truly an outsourcing. Organizations will reach levels of performance, excellence and maturity that as they become independent will move towards outsourcing (QUINN; COOKE; KRIS, 2000).

Still in this context, Schulman, Harmer and Lusk (2001) warning that the shared service center that chooses to provide services externally needs to be aware of all the costs involved in this change. Especially the cost of culture change, but the theory primarily addresses the financial cost of maintaining a service delivery structure, much more dangerous than choosing to deploy a shared service center for example.

The adoption of an outsourcing is to hire a company specialized in some area to carry out activities in which the company believes it is not advantageous to produce it, this can be derived for several reasons, as for example the lack of knowledge or option to reduce costs by a secondary activity (ABRAMOVSKY, GRIFFITH; SAKO, 2004). A shared service center when compared to internal outsourcing can be seen many conversion points, for this reason is also known as internal outsourcing (BANGEMANN, 2005).

\subsection{IMPLEMENTATION OF SS}

The choice of a way for the company should always be based on a deep analysis and a long-term strategy, the disengagement in the middle or a mistaken change can lead the company to failure. Therefore, in the moment that the decision is made by the organization for the creation of shared service center, until actually implementing there are several processes and steps to be followed. Porter (1999) mentions a list of prerequisites to be analyzed in order to adopt the sharing:

- Competitive advantage: sharing must benefit the competitive advantage;

- Costs: never should be greater than the benefit; 
- Resistance to change: any change generates impacts; it is important to anticipated, measure and treat them;

- Strategic structure: the organization that holds the activity and knowledge must be able to move to the business unit;

- Hierarchy: planning must reach all hierarchies of the company;

- High Administration: must be the guiding of the process;

- Measure: it is important to measure the goals that have been achieved;

\subsubsection{In the context of strategy}

There are many definitions for strategy in literature, Peng (2006) defines strategy as a mixture of actions, planned or not, to gain competitive advantage and is defined by the following factors: competitors, talents, know how, organizational structure and performance (PENG, 2006).

Porter (1996) presents strategy as a mix of actions that aims to leave company ahead of competitors, and in this way, a privileged position. To reach this level of success it is important to deliver superior quality services, and especially focus your efforts on the vital activities of the company, and in this way leave support and support activities in the background. In a globalized market, it is only possible to surpass competitors by means of a strategy aligned and guided by the objectives of the company.

\subsubsection{In the context of organizational structure}

The organizational structure must be adapted and be the basis to support a shared services center, only in this way will it be possible to respond in an agile and quality way the changes imposed by the market.

Pereira (2004) notes that sharing as a business strategy must focus its efforts across the enterprise chain, in the so-called end-to-end, and not just in separate processes and activities. Pereira (2004) also notes that, because the structure is more dynamic and flexible, it should be used to give more speed to respond to the increasingly competitive market and prioritize the company's main activities.

\subsubsection{In the context of technology}

Technology has revolutionized the world and continues to revolutionize today, but at a speed that may and will directly affect today's forms of work.

Technology is defined as the grouping of several technological tools to ensure a competitive advantage over its competitors (REZENDE; ABREU, 2003).

Therefore, according to Reily and Williams (2003), the potential of growth for SS is directly related to the advancement of technology.

According to Teixeira and Campos (2002) the advance of technology generates 2 immediate impacts to the companies: the possibility of greater interaction between the several areas of the organization and causes creation of new organizational structures.

According to Pisarczyk (2010) the implementation of a shared service allows the company to reorganize its structure and processes, allowing an optimization of its resources through the use of technology.

\subsubsection{In the context of process}

The consulting firm Deloitte presented a study in which most companies start their SS with simpler processes, and after stabilizing, migrate to more complex processes. In Addition, Cooke (2006) notes that success for SS is streamlined and standardized services. In this sense, according to Ulrich and Grochowski (2012), shared SS main function is to deliver a privileged position in relation to the competition. 
The success of a CSC can be defined when support activities becomes essential for the organization, favoring the best application of accessible resources and technologies (BEARD; RUPP, 2004).

\subsubsection{In the Context of People and career}

According to Ramos (2005) the creation of a CSC is a profound change for the company, and especially for the people, the management of change involves several personal challenges, such as: resistance to change, motivation, reduction of personnel, diversity of cultures.

Magalhães (2009) carried out a study in which he analyzed the barriers found for SS success. The result was of 10 items found, 6 are linked to a lack of change management, this point indicates that the evaluation of the change was not done correctly and in this way the result obtained did not meet expectations and the expected benefits were not achieved or generated a service different from the expectation.

In this same line of thinking, Shculman, Harmer and Lusk (2001) note that the worst obstacles are linked with people, in other words, resistance to change can be an obstacle to the success of a SS. Is important negotiate people's expectations in relation change in policies and procedures, training of new technologies, company controls, are all factors that directly affect the company's culture.

\section{CASE STUDY}

Due to confidentiality, the company studied will be called "Tobacco". Tobacco has a centuries-old history, founded in 1903 when its creator put into operation the first machine to produce cigarettes already rolled in paper. In 1914, its founder passed the ownership control to a Global group. In the year 1957, Tobacco affiliated to the São Paulo Stock Exchange. Twelve years later, in 1969 the process of exporting tobacco began. In 1978, the plant inaugurated in Minas Gerias, which until today is the largest in Latin America. In 1994, the largest integrated cigarette distribution center in Latin America inaugurated in São Paulo. In 1995 Brascuba, a joint venture of Tabaco and the Cuban state-owned company, was founded. In 2007, the company's new Research and Development Center, one of the most advanced in the world, is inaugurated. By 2015, the global group decides to close capital, and repurchase the market shares.

\subsection{VISION, MISSION AND VALUES}

The information below are in the company's website:

- The vision of the company: Tobacco's vision is to lead the Brazilian market of tobacco products in a responsible and innovative way, ensuring the sustainability of the business through the development of our talents and our brands.

- Sustainability: Sustainability is a Tobacco Commitment. The company believes in the production of better and solid long-term economic results from the adoption of behaviors and socially responsible practices.

- Who we are: Pioneering, innovation, responsibility, commitment to quality and sustainability. With a history based on these concepts, Tobacco is today the leader in the national cigarette market.

\subsection{TOBACCO IN NUMBERS}

The company is present in all parts of Brazil, with a percentage of approximately $75 \%$ of the legal market in the Country. Revenue in the year 2016 was R\$ 16 Billion. Tobacco has 7 thousand employees, which at the time of the tobacco harvest can reach 11 thousand. 


\subsection{Tobacco's Shared Service Center}

The company has had a site called the shared service center since 2009, but only in 2015 that the activities and structure were actually migrated to this location as it is today. And during this period it underwent some relevant changes, which made possible today to become a business differential for Tobacco.

The company has gone through huge changes to adapt to the market that is proving more challenging every day for the company's business. And the shared service center is the focus in this process of adaptation. Tobacco also implemented a shared service center, with the objective of gaining scale, standardizing services, and focusing on the core business of the company. Today, financial services as accounts payable, accounts receivable, etc., as well as HR services such as sheet processing, hiring and termination, and information technology services such as Help Desk.

In the first moment, despite the Shared Service center is geographically separated from the headquarter, that is in Rio de Janeiro and the SS is in São Paulo, for the business there was no differentiation, as for example the budget and the hierarchy that still were not dissociated.

The group in 2010 bet on a project to have a global system in which it would be possible for all companies in the group to have the same standardization of accounts, cost center, etc. In addition, through this project the SS came to have a fundamental position within the Group, since the final markets could focus on the business of the company, while the CSC would take care of the Back office, including with a single CSC consolidating information of several distributed companies in several countries.

The project was implemented in all the companies of the world at the end of 2015. At this moment the CSC became a separate entity, with own budget, structure and global directive, totally separate from Tobacco. The shared services center in Brazil (there are 2 more in the world) serves only Tobacco because of its representativeness for the Group and its complexity due to the innumerable specificities of Brazil.

In order to continue the process of continuous improvement and maintain the position achieved, the CSC is investing in another project, the further automation of processes through the deployment of robots, in which it allows routine and standardized processes to be made programmatically. Tasks that took hours to complete can be done in minutes. This new technology is known as RPA.

In parallel, the group is migrating worldwide from a Shared Service vision to a Global solutions vision, known as GBS, which tends to be the new evolution of Shared Service structure.

\subsection{Results Analysis}

The results were divided according to the theory approached, in order to confront the perception in the organization's vision. In this way, the results are divided into 5 groups, which are: strategy, organizational structure, processes, people and career, and technology and communication.

A relevant fact verified during the surveys, that besides variations of perceptions between the employees of the Shared Service and the End Market, there are variations between levels hierarchical, in this way was added the analysis between Analysts that represent $31 \%$ of the total researched, the Coordinators the $31 \%$ and Managers representing $38 \%$.

\subsubsection{Strategic Results}

In the first result we can see how the perception, in general, of the service developed by the Shared Service. In this result, 2 points draw attention 
- Only 36\% of EM perceives Shared Service as an essential factor for the strategy, compared to $53 \%$ in the SS vision.

- Approximately $40 \%$ of SS respondents believe that the work they do provides some or a good contribution to the strategy. In this way we can affirm that most of the collaborators see no value in the work done by them.

Analyzing the same question for the vision at the hierarchical level, we can see that only among the coordinators the option "essential to the strategy" was not the first one, and the coordinators of the SS itself represent $75 \%$ of this total.

The next point deals with the employees' perception about SS adds value to the company become a differential to company.

The result reinforced the previous item that the perception of the SS in the work done is worse than the perception of the Client (EM) in relation to delivery of value to the EM, level expected by the theory is align with EM.

The analysis by function bring the possible to identify that the perception of value by the lower levels in the hierarchy is greater than in the managerial levels. This fact can be explained by a more managerial and holistic view of managers and coordinators, while analysts are more focused in a small part of work, on their activities

This point seeks to identify if another form of organization, in this case outsourcing, can perform the same work done by the SS.

- Again, the EM perceives more value in the work delivered than the SS, approximately $57 \%$ answered that it would not be possible for an outsourced company to perform the same level of service delivered today by the SS;

- The second point is surprising, because $13 \%$ of Shared Service respondents believe that outsourcing could deliver a better job.

When we analyze by function in companies. We may note that respondents who believe that an outsourced company could do a better job, it is divided between analysts and coordinators. Another possible analysis is that a part of the managerial level, approximately $17 \%$, that is not so sure of a better delivery by the SS, about $14 \%$.

This question had as objective to analyze the perception in relation to the greater benefits addressed by the theory.

The standardization and optimization of services in both companies was the option with the greatest number of responses. It is important to note that $33 \%$ of MS recognizes an improvement in quality.

The result was standardized among the hierarchical classes, only the point of quality improvement was more perceived at the levels of analysts and coordinators than of managers. Probably it is directly related to the perception of the improvement of the way of working, in other words, it is possible to obtain information with more quality and agility due to the new structure.

\subsubsection{Process Results}

The SLA is an agreement between the parties that define the work to be performed, response time; among others. It is important to mention that there is no such contract between the SS and the EM. This reflects whether the percentage of SS responses, approximately 73\%, believe it to be essential to have this type of agreement for service delivery.

The perception of importance by hierarchical level is concentrated in managerial levels of both structures. At the lowest levels, analysts, given less importance for this item.

The purpose of this question is to investigate the speed of the process given the demand for EM. No respondents believe the SS has a response time rated as optimal. However, 21\% of MS answered that the response time is "bad". Faced with this result, is 
necessary take some actions to revert it, because represents an important indicator for service delivery.

Regarding the point cited in the previous analysis, of the total of managers who responded as bad the response time, 66\% are in EM.

About more standardized and routine activities, we have the following results: $100 \%$ of MS rates as "good" or "very good".

levels.

In this topic, specifically, there were no major divergences between hierarchical

This item seeks to bring the perception between services requested for a specific subject, outside the normal routine. How is treated the time for attend? A large majority of EM (73\%) classified as a negotiated activity, confirmed by $57 \%$ of SS responses, but $28 \%$ of MS believe they have a level of urgency and priority for their requests.

There is an equivalent distribution among the hierarchies, but for the urgency mentioned in the previous graph, it is possible to notice that the sense of urgency is concentrated in the managers and coordinators of the MS.

The perception of quality improvement and the expectation of improvement is the central point of this item. There are a stability of information, and a good expectation of improvement over time, because the objective of the SS is to offer a long-term service, with a constant and lasting growth without performance peaks.

It is possible to identify a response pattern, it is noteworthy that most managers, who usually have a more critical view, have the best evaluation between the 3 groups.

\subsubsection{Structure Results}

The objective of this topic is to identify the organizational structure among companies thinking about a service delivery relationship. It is worth remembering that the SS has a separate organization of the MS, responding directly to a specific SS Hierarchy, a change that occurred approximately 1 month before the survey, perhaps this reason could explain the result so dispersed, and would explain that less than $40 \%$ have answered correctly.

When looking at the "Same Group" response, it is possible to notice that only the managers responded this option, as the change of structure was made soon, it is possible that the cascade was not done in the best way possible.

Related to the above topic, most of employees, about $71 \%$ and $33 \%$ ranked with a partnership relationship, not considering as a service provider, which affects, directly, the relationship between them.

There is a standardization of responses independent of the function it performs.

\subsubsection{People and career results}

The goal in this section is to check the career expectations and the points relative to people presented in this model.

Analyzing the perception about the maturity and knowledge available in SS, the concentration of responses was between "good" and "very good", but it is important to highlight that $21 \%$ of EM considered as "bad".

It is possible to contemplate that in the classification by hierarchical level the classification "bad" was concentrated among the managers, in which $75 \%$ of this metric was of the MS. In other words, for the higher levels of management there are still a knowledge gap to support activities in the right way.

On career opportunities, the vast majority believe that visibility and opportunities are smaller for SS workers.

Much of this impact can be understood analyzing each hierarchy separately; the group of analysts and coordinators concentrate most of the negative responses. 
The challenges faced by the contributors in the careers and the possibility of developing their skills is approached in this topic. According to the previous item, the perception that MS has more advantages remains.

The perception of routine and standardized activities are the main drivers of this perception that is shared by all levels.

In case the EM requests new information, how would it classify the support given by the SS. In general, the result was satisfactory, being between "good" and "very good". Point of attention for the $7 \%$ of "very bad" reported by the EM.

In general, does not note variations between the hierarchies, but it is possible to say that $100 \%$ of "bad" answers comes from managers.

This item analyzes the reliability of the information, $100 \%$ of the respondents of the MS rank with a good level of reliability, but the SS is responsible to create the distortions, as $7 \%$ in totally reliable, and another $7 \%$ with little reliability.

When performing the open analysis by function group, realize that the distortions generated comes from the coordinators, relies totally and from a manager, who says he relies little on the information generated by the SS.

\subsubsection{Communication and Technology Results}

This topic aims to analyze how the communication and technology factors affect the work between SS and MS.

The classification of communication was concentrated between "good" and "very good" which is a satisfactory level for this item.

Analyzing the result by hierarchical group can see that the greater distortions, "great" and "bad" were centered in the answers of the managers

In case the EM needs an information, the employees knows who and where to look for? Who are the key people? By consolidating positive answers, it is possible to say yes.

Checking the table below it is possible to verify that there is no distortion of results between the analyzed groups.

This part of the research seeks to investigate the impact of the technology for the provision of service, as shown in the table below.

It is concluded for the vast majority technology is of fundamental importance for the strategy and support of the company's activities

When analyzing by hierarchical level, noted the managerial level has a more comprehensive vision and a higher impact level than the other groups in this topic.

\section{CONCLUSION AND RECOMMENDATION FOR FUTURE WORK}

The Shared Service, as a service provider, needs put together several knowledge and work tools to develop a high level performance, and this performance needs to be understood by the client, in other words, who will receive the service needs to be sure that is buying the best available on the market in terms of quality and performance.

The Shared Service is an organization in constantly change and gives a quick response to market and the company, it can support simple tasks, for example Account Receivable and Account Payable, and process more complex, effectively contributing to company strategy. This flexibility favors the implementation of new way to organize the companies, it can be identified in a several sectors of economy, being private or public. Besides to response more quickly the demands than a traditional organization, but mainly for the fact to be dedicated a specific tasks groups, in which the control and velocity is easier to be measured than bigger and consolidated structures.

An important point identified are the new way of work, in other words, the new 
challenges that can happen with the Shared Service expansion. The function of specialist, the person who makes a specific job with excellence, is fundamental to Shared Service works well. While the company holistic view and process are not valued, thus to develop a specific knowledge for the few tasks is a restrictive point to a career outside of Shared Services companies, or will be conditioned to develop the whole career in this type of company.

The information technology is an essential tool that enable the possibilities of activities supported for the Shared Service, mainly for ERPs. With the technological advance, besides to help the performance in tasks execution, other fundamental point is to eliminate the distance existent between different units, so the Shared Service can do the same job, without any performance loss, to support an organization in the same physical space or in other country, for example. So the information technology provides a new way to work, without geographical limitation. This possibility can be called $3^{\mathrm{a}}$ wave. The first wave, is a conception of Shared Service and the first jobs done, simple process. The second, is a consolidated position and complex process. And the third, the company can choose the work with a deal, in other words, the Shared Service can perform simple or complex process, and any place in the world. Today, are called GBS, Global Business Services.

Regarding process we can conclude that scale gain is the recognize benefit of Shared Service, the cost reduction is derivate of efficiency gains. The cost reduction, is not just linked the process improvement, but in elimination of duplicated tasks, in other words, different places that do the same job, they are eliminated and concentrated in Shared Services Organizations. The centralization of tasks favors other point to cost reduction, bargaining power with suppliers for example, this must be perceived as a competitive advantage.

A very sensitive factor in Shared Services is a communication, there are many problems caused by a fail or missing communication, this process not depends in which phase the Shared Service maturity, we can find problems since implementation until more consolidated positions. Actually, this problem is a result of the people and not the company, and the problems happen in all hierarchy inside the company. Despite all technological power and available tools to facilitate the communication, we still find the basic mistakes inside the organization and between them. But the companies have been working hard, with new strategies and best practices, to correct past mistakes.

In resume, the Shared Services are a new way of organization and in constant change, even though find some problems with specific themes, there are many positive points and deliver value to End Market and contribute to strategy. The companies and academics are working to find a solution for the issues founded. Thus, the Shared Service could deliver your best.

As a recommendation for future work suggests a deeper analysis with a larger group of companies. Another suggestion is with technological advancement, local and regional SS are migrating to Global Solutions (GBS), an analysis of how this could affect the markets, especially the Brazilian, since it is one of the largest SS destinations in the world. A final option would be the analysis of new forms of work in the future, as automation, also known as RPA, could affect the jobs.

\section{REFERENCES}

[1] ABRAMOVSKY, L.; GRIFFITH, R.; SAKO, M. Offshoring of Business services and its impact on the UK Economy. Unpublished manuscript. 2004

[2] BANGEMANN, T. O. Shared Services in Finance and Accounting. England: Gower Publishing Limited, 2005

[3] BEARD, M.; RUPP, T. Moving Towards Global Shared Service Centers. 2004. 
[4] COOKE, F. L. Modeling an HR shared services center: Experience of an MNC in the United Kingdom. Human Resource Management, 45(2), p. 211-227, 2006.

[5] Delloite Shared Service Conference. Available at: http://www.deloitte.co.uk/sharedservicesconference/2016-highlights/. Accessed: 20aug-2018.

[6] Delloite shared services survey 2017. Available at: https://www2.deloitte.com/us/en/pages/operations/articles/shared-services-survey.html. Accessed: 20-Jul-2018.

[7] HOPE, J.; PLAYER, S. Beyond Perfomance Management. Harward Business Review Press, 2012.

[8] LA SALLE, Jones Lang. Invest in Poland, Onshore, Nearshore, Offshore: Unsure? 2009.

[9] MAGALHÃES, C. Passo a passo para planejamento, estruturação, estratégias e processos de um Centro de Serviços Compartilhados. São Paulo: Conexões Educação Empresarial, 2009.

[10] MILLER, C. A look at European shared service centers. Internal Auditor, October, 56, 5, p. $44-48,1999$.

[11] PATINO, M. ALMEIDA, G. PASETO, L. -Centro de Serviços Compartilhados das Empresas Multinacionais: Localização e Desafios Culturais. RMS - Revista Acadêmica das Faculdades Metropolitanas Unidas (FMU) - Revista Metropolitana de Sustentabilidade, vol. 4, n. 3, 2014.

[12] PENG; Mike. Global Strategy. Thomson South-Western, 2006.

[13] PEREIRA, N. A. F. Impactos da implantação do centro de serviços compartilhados sobre sistemas de controles: estudos de caso. 2004.

[14] PETKOVIC, M.; LAZAREVIC, S. Managing Interorganizational Relations: Design of Shared Services Centre. Management Journal, 64, p. 55 - 67, 2012.

[15] PISARCZYK, A. Hewlett-Packard's global business center in Poland as an example of a successful shared services center, 2010.

[16] PNIEWSKI, K.; KALAWA, W. Centra Usług Wspólnych, solidne wsparcie dla biznesu, Deloitte, p. 1- 9, 2009.

[17] PORTER, Michael. What is strategy? Harvard Business Review, 1996.

[18] PORTER, Michael E. Competição: estratégias competitivas essenciais. 2. ed. Rio de Janeiro: Editora Campus Ltda, 1999.

[19] PWC Survey 2017. Available: https://www.pwc.com.br/pt/estudos/setores-atividades/tmt/.../pesq_csc_22-02-17.pdf. Accessed: 02-sep-2018.

[20] QUINN, B.; COOKE, R. S.; KRIS, A. Shared services: mining for corporate gold. Financial Times, Prentice Hall, 2000.

[21] RAMOS, L. J. T. Serviços compartilhados como forma de estruturação organizacional. 2005. 
[22] REZENDE, Denis Alcides; ABREU, Aline França. Tecnologia da informação aplicada a sistemas de informação empresariais: o papel estratégico da informação e dos sistemas de informação nas empresas. 3. ed. São Paulo: Atlas, 2003.

[23] RICHTER, Philipp Clemente; BRUHL, Rolf. Shared service center research: A review of the past, present, and future. 2016.

[24] RUDZIONIENE, Kristina; SAKALAUSKIENE, Renata. Shared Service Center Factors and Return on Investment. ISSN 1392-0758 Social Sciences, 2014.

[25] SCHULMAN, D.; HARMER, M.; LUSK, J. Shared Services: agregando valor às unidades de negócios. São Paulo: MAKRON Books, 2001.

[26] TEIXEIRA, F.L.C.; CAMPOS, Edna. A adoção da tecnologia da informação nas organizações: uma proposta de análise do "modelo de estruturação da tecnologia" através da implementação de sistemas de groupware no site da ANPAD, 2002.

[27] Ulrich, D., \& Grochowski, J. From shared services to professional services. Strategic HR Review, 11(3), p. 136-142, 2012.

[28] VERGARA, Sylvia Constant. Projetos e Relatórios de Pesquisa em Administração. 12. ed. São Paulo: Atlas, 2010. 